\title{
The bionomics and diversity of freshwater snails species in Yewa North, Ogun State, Southwestern Nigeria
}

\author{
O. T. SALAWU ${ }^{1,2^{*}}$, A. B. ODAIBO ${ }^{2}$ \\ ${ }^{1}$ Department of Biosciences and Biotechnology, Babcock University, Ilishan-Remo, Ogun State, Nigeria, \\ *E-mail: zootund@yahoo.com; ${ }^{2}$ Parasitology Research Unit, Department of Zoology, University of Ibadan, Nigeria
}

\begin{abstract}
Summary
Snail control as a form of integrated control for schistosomiasis has been strongly advocated but data on biocontrol using competitor snails are relatively lacking in most endemic areas. Monthly sampling of freshwater snails was conducted in four water bodies in Yewa North Local Government Area, Ogun State, Nigeria. Monthly in situ measurements of the physico-chemical characteristics of surface waters were carried out using field meters. A total number of 13 snail species were recovered from the water bodies. Of these, Bulinus camerunensis was reported for the first time in Nigeria. A significant positive relationship occurred between snail density and dissolved oxygen. Other important relationships were those between Lanistes lybicus and Bulinus senegalensis, Bulinus globosus and Bulinus jousseaumei, and B. senegalensis and Segmentorbis augustus. Snail control using competitor snails should be integrated into schistosomiasis management programmes in endemic areas in order to prevent residual schistosomiasis transmission after control intervention through mass drug treatment.
\end{abstract}

Keywords: schistosomiasis, freshwater snail diversity, physico-chemical parameters, biocontrol, Nigeria

\section{Introduction}

Schistosomiasis continues to be one of the most important and widespread neglected parasitic diseases in Nigeria especially in areas with poor water supply. The interplay between the infective stage of the causal organisms 'Schistosoma spp.' which develop within specific snail and human definitive hosts when in contact with the transmission foci has been the incriminating factor.

Schistosoma haematobium is transmitted through snails primarily of the genus Bulinus, which contains around 37 species within 4 species groups. Bulinus spp. are extensively distributed throughout much of Africa, Madagascar, parts of the Middle East and Mediterranean (Brown, 1994). However, the intermediate host-parasite relationship is complex, in terms of specificity and compatibility, with both genetic and environmental factors playing a role in determining small-scale heterogeneities in schistosomiasis transmission (Rollinson et al., 2001).

Environmental factors affect the distribution patterns, the life cycles and population dynamics of snails and hence patterns of transmission (Rollinson et al., 2001). General studies on the ecology of freshwater snails in Nigeria have considered rainfall, $\mathrm{pH}$, oxygen concentration, conductivity and presence or absence of macrophytes (Ndifon and Ukoli 1989; Olofintoye \& Odaibo, 1996; Owojori et al., 2006).

The majority of studies on schistosomiasis laid emphasis on disease prevalence andintensity of infection among human populations with little or no emphasis on the intermediate snail hosts.Some of such studies involving the local spatial and temporal transmission patterns for $S$. haematobium include those in Zanzibar (Rudge et al. 2008), in Tanzania (Hamburger et al., 2004), in Niger (Labbo et al., 2008), in Kenya (Clennon et al., 2006), in Nigeria (Oladejo \& Ofoezie, 2006), and in the Senegal River Basin (Opara et al., 2007).

This study aims to assess the freshwater snails' distributions and the interactions between them in order to device a possible Schistosoma biological control measure in the study areas. In addition, we also assessed the physicochemical factors that may influence snail distribution.

\section{Materials and methods}

\section{Study area}

The study was conducted in four river bodies in Yewa North Local Government, Ogun state, Nigeria. These river bodies are major water bodies with very high degree of human-water contact. The Local Government Area (LGA) 


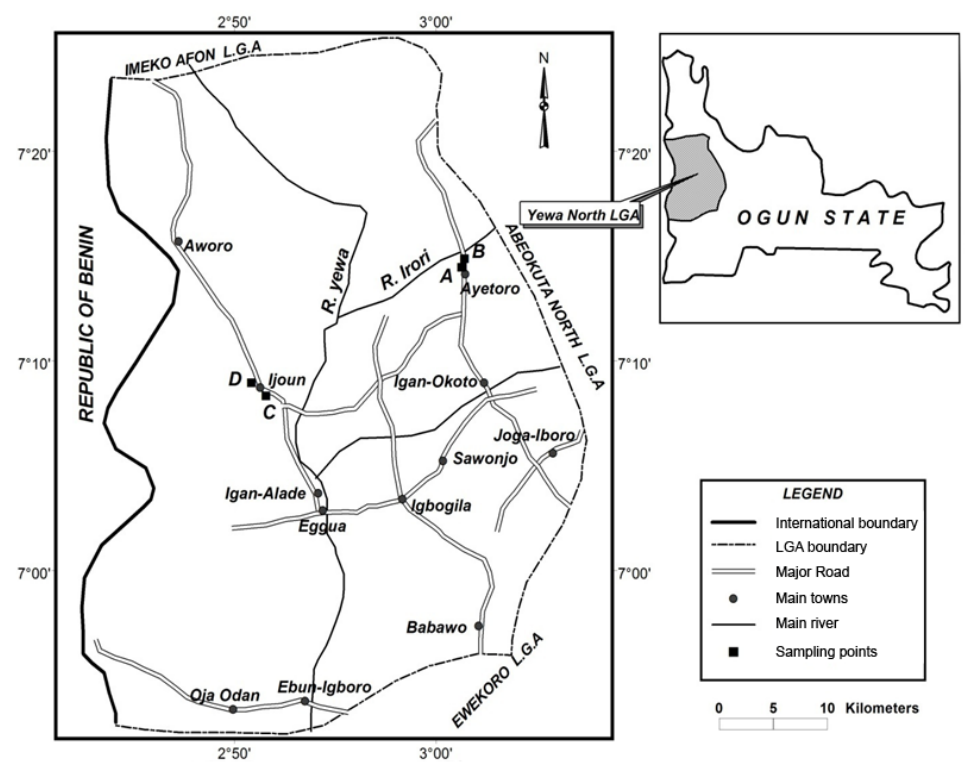

Fig. 1. The Map of Yewa North LGA, Ogun State, Nigeria

$$
\text { A - river Bareke, B - Irori, C - Idi, D - Isopa }
$$

has the largest land area in the Ogun state and is located in latitude $7^{\circ} 15^{\prime} \mathrm{N}$ and longitude $3^{\circ} 3^{\prime} \mathrm{E}$ in a deciduous/derived savannah zone (Onakomaya et al., 1992). The LGA is one of the most endemic communities for S. haematobium in Ogun State, Nigeria (Mafiana et al., 2003; Ekpo et al., 2008). A preliminary study conducted by our group in the area revealed a prevalence of $54.8 \%$ in school children (Hassan et al., 2012), 9.8\% in preschool children (Salawu \& Odaibo, 2014) and $21.5 \%$ in pregnant women (Salawu $\&$ Odaibo, 2013). The endemicity of the disease is due to lack of good water sources thereby compelling the community dwellers to depend on water from river bodies for their domestic uses (Salawu \& Odaibo, 2013).

\section{Snail sampling}

Snail samplings were carried out in four water bodies including Bareke (depth $88.9 \pm 8.5 \mathrm{~cm})$, Orori $(93.8 \pm 11.1 \mathrm{~cm})$,
Idi $(132.5 \pm 17.1 \mathrm{~cm})$ and Isopa rivers $(195.5 \pm 204 \mathrm{~cm})$ located in Ayetoro and Ijoun communities (Fig. 1). The predominant aquatic macrophytes in all the water bodies include Nymphaea lotus, Polygonum senegalense, Echinochloa pyramidal and Vossia cuspidate. The selection of the four water bodies was based on the degree of humanwater contact activities. All sites of sampling are representative of the water bodies. Only one site in each water body was sampled with the same visited each month. Two river bodies (Bareke and Orori) were selected in Ayetoro town (a peri-urban settlement). The other two water bodies (Idi and Isopa) were located in Ijoun (a typical rural settlement). Snails were randomly sampled for 20 minutes along the littoral zones where human-water contact activities occurred using a long handled scoop $(0.2 \mathrm{~mm}$ mesh) net once every month from February, 2010 to January, 2012 (Olofintoye \& Odaibo, 1996). Each scoop

Table 1. Abundance of freshwater snails species in selected rivers in Yewa North LGA, Ogun State

\begin{tabular}{lcccccc}
\hline \multirow{2}{*}{ Snail species } & \multicolumn{5}{c}{ River bodies } & \\
\cline { 2 - 5 } & Bareke & Orori & Idi & Isopa & Total & \% Abundance \\
\hline Melanoides tuberculata & 63 & 0 & 19 & 27 & 109 & 12.9 \\
Potadoma moerchi & 2 & 0 & 26 & 17 & 45 & 5.3 \\
Lanistes lybicus & 27 & 91 & 36 & 122 & 276 & 32.6 \\
Bulinus globosus & 0 & 0 & 2 & 6 & 8 & 0.9 \\
B. senegalensis & 28 & 2 & 2 & 8 & 40 & 4.7 \\
B. camerunensis & 25 & 0 & 0 & 5 & 30 & 3.5 \\
B. jousseaumei & 0 & 0 & 0 & 9 & 9 & 1.1 \\
Segmentorbis augustus & 9 & 0 & 0 & 2 & 11 & 1.3 \\
Ferrissia sp & 37 & 13 & 60 & 29 & 139 & 16.4 \\
Biomphalaria pfeifferi & 0 & 0 & 0 & 1 & 1 & 0.1 \\
Gyraulus costulatus & 1 & 1 & 56 & 115 & 173 & 20.4 \\
Lymnaea natalensis & 0 & 0 & 0 & 5 & 5 & 0.6 \\
Number of species & 10 & 5 & 8 & 13 & 13 & \\
Total & 192 & 107 & 201 & 346 & 846 & 100 \\
\hline
\end{tabular}


was thoroughly searched and all snails collected were kept in pre-labeled plastic containers containing wet cotton wool. The container was then covered with perforated lids and was taken to the laboratory where they were washed, identified and counted (to determine the number of each snail species collected per month). Bulinus camerunensis was identified based on the presence of aperture more than the half of the body and somewhat broad shell. The snails were identified using reference specimens from the Danish Bilharziasis Laboratory Charlothenlund, Denmark. The vouchered collection of the specimens was housed in the Department of Zoology, University of Ibadan, Nigeria.

\section{Measurement of physico-chemical parameters}

Monthly in situ determinations of water temperature, $\mathrm{pH}$, total dissolved solid (TDS) and conductivity were carried out using the electronic combined meter (model M1806). Dissolved oxygen (DO) was determined using DO meter (model MW600). The rainfall data was obtained from the Meteorological Station in Abeokuta, Ogun State Nigeria. Sampling was done usually between 9 a.m. and 12 p.m.

\section{Data analyses}

Data were entered into an Excel spreadsheet, checked for entry errors and transferred into SPSS for Windows (version 17.0, SPSS Inc, Chicago, USA) for analysis. A Oneway Analysis of Variance (ANOVA) was used to compare the difference in snail abundance between water bodies. Post-hoc Bonferroni adjustment (where appropriate) was used to account for multiple comparisons. Karl Pearson's equation of coefficient of correlation was used to assess the relationships between snail abundance and the physicochemical parameters, and biological interactions between different snail species. Snail diversity index for species richness was determined using Margalef's diversity index
(Margalef 1951). Shannon Wiener index $(\mathrm{H})$ was used for the general diversity and evenness (E) of distribution (Ajao, 1990). The P-values $<0.05$ were considered statistically significant.

\section{Results}

\section{Diversity and distribution of snails}

Thirteen species of snails belonging to six orders and eight families were recovered from the water bodies. A total number of 846 snails were recovered from the rivers. Of these, B. camerunensis (Mandahl-Barth, 1957) was reported for the first time in Nigeria (Fig. 2). Isopa River was richest water course in snail species (Table 1). Irori River had the least, with only four species. The total number of snails sampled throughout the sampling period also followed a similar pattern with Isopa (338) and Irori (107) having the highest and least number respectively. Lanistes lybicus (Morelet, 1848) (276) was the most abundant while Biomphalaria pfeifferi (Krauss, 1848) (1) constituted the least number (Table 1). Lanistes lybicus, Bulinus senegalensis (Müller, 1781), Gyraulus costulatus (Krauss, 1848) and Ferrissia sp. (Walker, 1903) were present in all the four rivers. Two snail species B. pfeifferi and L. natalensis were found only in Isopa River. Bareke, Isopa and Idi rivers had the highest relative abundance of Melanoides tuberculata (Müller, 1774) (57.8\%), L. lybicus (33.3\%) and Ferrissia sp. (43.2\%) respectively.

Generally snail abundance varied significantly across the river bodies $(\mathrm{P}<0.05)$. However, results from multiple comparisons showed no significant difference in the snail abundance of Idi and Isopa rivers. The diversity of snails in Bareke river was significantly higher than those of other rivers $(\mathrm{P}<0.05)$. However, there was no significant difference in snail diversity of Isopa and Idi rivers (Table 2).
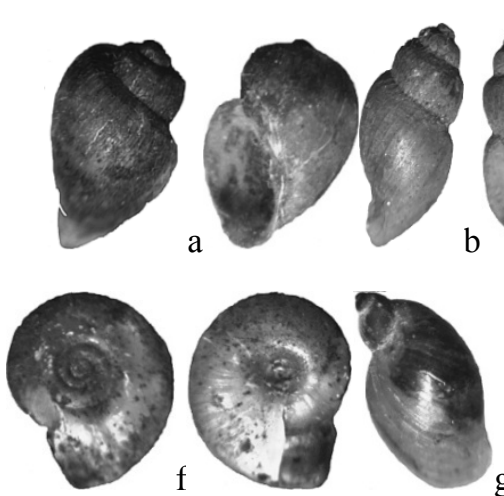
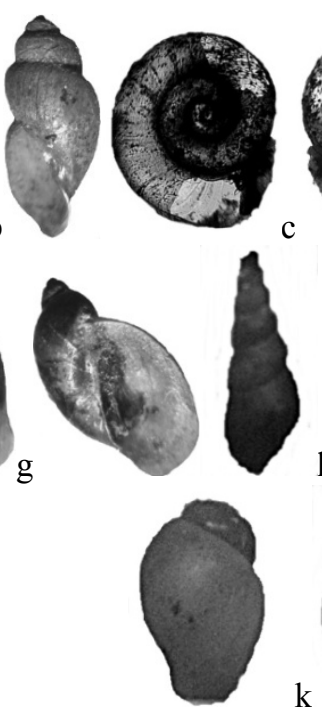
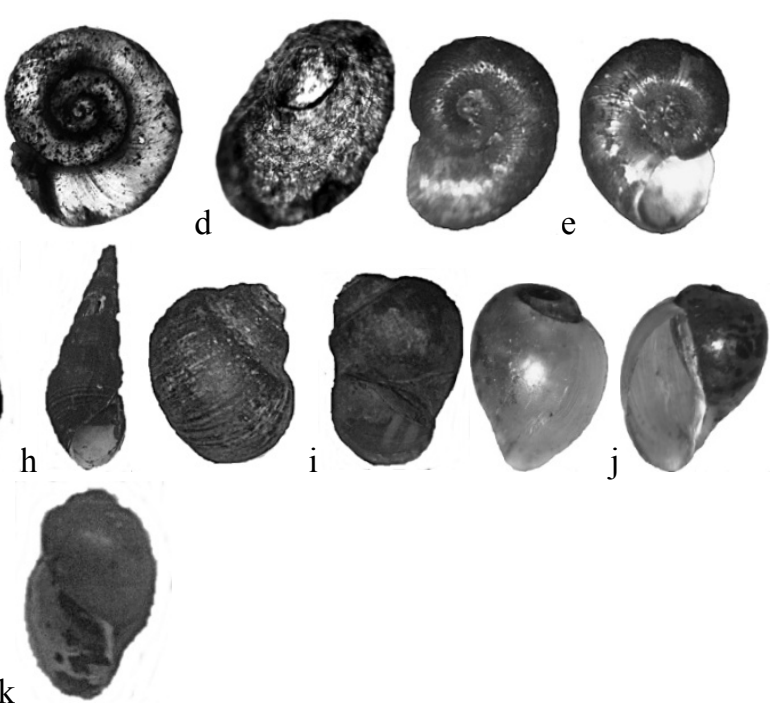

Fig. 2. Snail species recovered from the selected river bodies

a. Bulinus camerunensis $(3.0 \mathrm{~mm})$; b. B. senegalensis $(5.0 \mathrm{~mm})$; c. Biomphalaria pfeifferi $(3.0 \mathrm{~mm})$; d. Ferrissia sp (3.0 mm); e. Gyraulus costulatus $(3.0 \mathrm{~mm})$; f. Segmentorbis augustus (3.0 mm); g. Lymnaea natalensis $(9.0 \mathrm{~mm}) ;$ h. Potadoma moerchi $(21.0 \mathrm{~mm})$; i. Lanistes lybicus (29.0 mm); j. B. jousseaumei $(6.0 \mathrm{~mm})$; k. B. globosus $(8.0 \mathrm{~mm})$; 
Table 2. Biodiversity indices of snails in selected rivers in Yewa North LGA, Ogun State

\begin{tabular}{lllll}
\hline Indices & Bareke & Irori & Idi & Isopa \\
\hline Species Richness Index (d) & $1.676^{\mathrm{a}}$ & $0.841^{\mathrm{b}}$ & $1.301^{\mathrm{c}}$ & $2.053^{\mathrm{d}}$ \\
Shanon-Weiner Index (H) & $0.822^{\mathrm{a}}$ & $0.324^{\mathrm{b}}$ & $0.760^{\mathrm{c}}$ & $0.741^{\mathrm{c}}$ \\
Shanon Index (H') & $1.893^{\mathrm{a}}$ & $0.746^{\mathrm{b}}$ & $1.750^{\mathrm{c}}$ & $1.706^{\mathrm{c}}$ \\
Evenness Index (E) & $0.762^{\mathrm{a}}$ & $0.300^{\mathrm{b}}$ & $0.811^{\mathrm{c}}$ & $0.687^{\mathrm{d}}$
\end{tabular}

Note: similar alphabets denote no significance difference while different alphabets denote there were significant differences

Snail densities were generally higher in the dry season with a total of 460 and 379 snails recovered during the dry and wet seasons respectively. The early rainy period of the second wet season (May, 2011) recorded the highest snail abundance (78) while the late rainy period of the first wet season (October, 2010) had least snail density (12) (Fig. 3). An inverse relationship existed between snail density and rainfall pattern of the area.

Seasonal variations in physico-chemical parameters and relationships with snail density

Generally, temperature varied significantly in the different water bodies $(\mathrm{P}<0.05)$. However, the results of the multiple comparisons of temperature in different locations showed no significant variation in temperature values in Bareke and Irori Rivers. The mean temperature values in the dry and wet seasons were $25.4 \pm 2.1^{\circ} \mathrm{C}$ and $25.7 \pm 1.1^{\circ} \mathrm{C}$ respectively. The relationships between temperature and snail abundance varied with different species of snails. Increasing in temperature showed significant positive correlations with $G$. costulatus $(\mathrm{r}=0.336 ; \mathrm{P}<0.01)$ and $B$. globosus (Morelet 1866) $(\mathrm{r}=0.272 ; \mathrm{P}<0.05)$. Although not significant, negative correlations were observed between temperature and abundance of $M$. tuberculata, $B$. camerunensis, B. senegalensis and L. natalensis.

There were similarities in the $\mathrm{pH}$ variations in the river bodies. Bareke River had the least mean $\mathrm{pH}$ value $(6.7 \pm 0.9)$ while others had 6.9 each (Table 3$)$. The overall mean $\mathrm{pH}$ value was $6.9 \pm 0.8$ with values ranging from the minimum value 5.3 recorded in Idi River (December, 2010) to 8.6 recorded in Irori River (June, 2010). There was no significant variation in $\mathrm{pH}$ values of the river bodies. The $\mathrm{pH}$ also showed no significant variations with seasons but higher in the dry season $(6.9 \pm 0.9)$ than the wet season $(6.8 \pm 0.8)$. The $\mathrm{pH}$ of the water bodies showed significant positive correlation with the abundance of G. costulatus $(\mathrm{r}=0.292 ; \mathrm{P}<0.05)$, however, the positive relationship was not significant with the abundance of $B$. globosus and $B$. senegalensis. Negative relationships were observed between $\mathrm{pH}$ of the rivers and the following aquatic snails; L. lybicus, P. moerchi and L. natalensis.

There was a wide variation in dissolved oxygen values across sampling sites. The overall mean value of dissolved oxygen was $6.1 \pm 4.6 \mathrm{mg} / \mathrm{L}$ with values ranging from $1.02 \mathrm{mg} / \mathrm{L}$ in Bareke River (June, 2010) and Irori (MarchJune, 2010) to $17.2 \mathrm{mg} / \mathrm{L}$ in Isopa River (May, 2011). Bareke River had the smallest mean dissolved oxygen value $(3.4 \pm 2.0 \mathrm{mg} / \mathrm{L})$ while Isopa River recorded the highest mean dissolved oxygen value $(8.1 \pm 4.9 \mathrm{mg} / \mathrm{L})$. Generally dissolved oxygen varied significantly with the river bodies and seasons $(\mathrm{P}<0.05)$ with dry seasons recording higher mean value $(6.3 \pm 3.9 \mathrm{mg} / \mathrm{L})$ compared with the wet seasons $(6.0 \pm 5.1 \mathrm{mg} / \mathrm{L})$. Dissolved oxygen showed significant positive correlations with L. lybicus $(\mathrm{r}=0.387 ; \mathrm{P}<0.01)$, Ferrissia sp. $(\mathrm{r}=0.356 ; \mathrm{P}<0.01)$ and $L$. natalensis $(\mathrm{r}=0.324 ; \mathrm{P}<0.01)$.

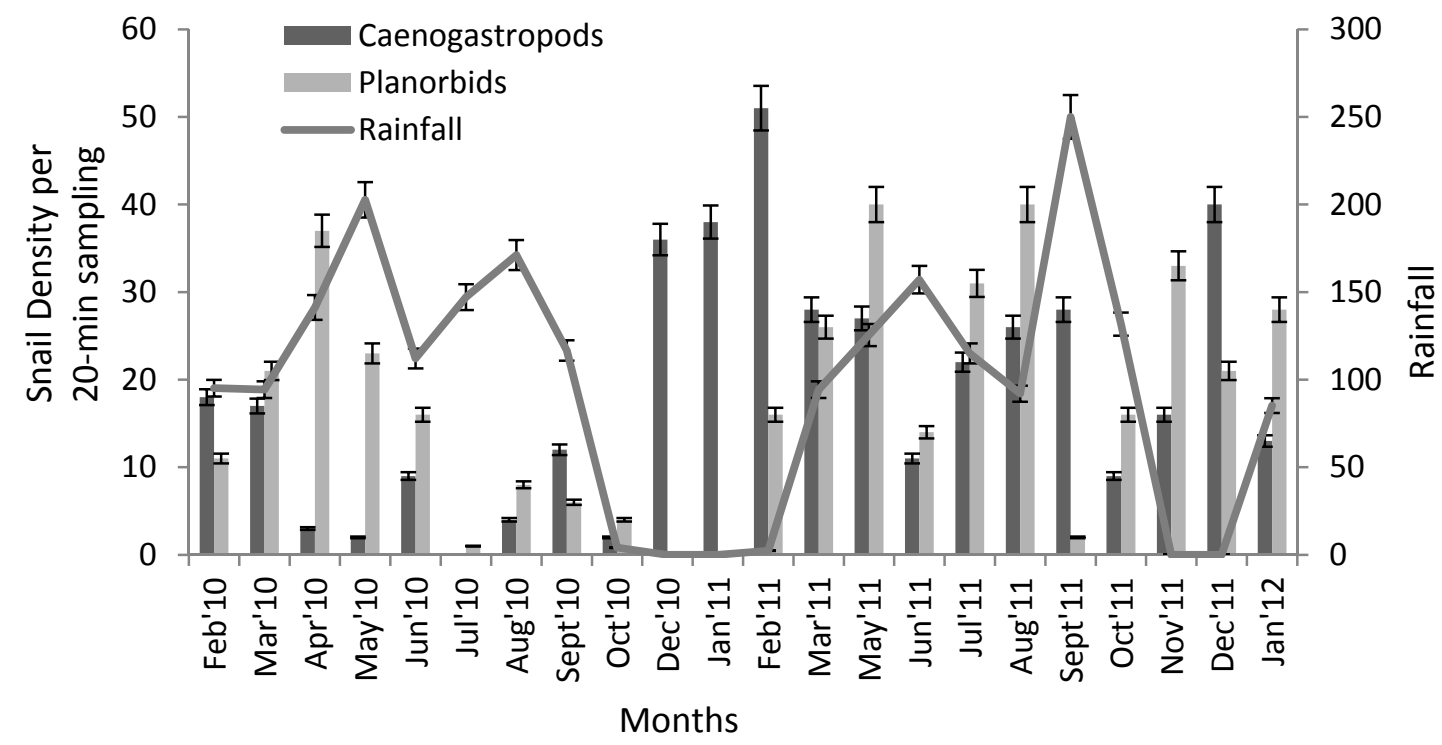

Fig. 3. Monthly variation in snail density in relation to rainfall pattern in selected river bodies in Yewa North LGA, Ogun State 
Table 3. Variations in physicochemical parameters of selected water bodies

\begin{tabular}{|c|c|c|c|c|c|}
\hline \multirow[t]{2}{*}{ River bodies } & \multicolumn{3}{|c|}{$\begin{array}{c}\text { Physicochemical parameters } \\
\text { Mean } \pm \text { SD (Range) }\end{array}$} & \multirow[b]{2}{*}{ Cond $(\mu \mathrm{S} / \mathrm{cm})$} & \multirow[b]{2}{*}{ TDS (mg/L) } \\
\hline & $\operatorname{Temp}\left({ }^{\circ} \mathrm{C}\right)$ & DO (mg/L) & pH & & \\
\hline Bareke & $\begin{array}{c}25.2 \pm 1.5 \\
(21.8-28.0)\end{array}$ & $\begin{array}{l}3.4 \pm 2.0 \\
(1.0-6.8)\end{array}$ & $\begin{array}{c}6.7 \pm 0.9 \\
(5.5-8.5)\end{array}$ & $\begin{array}{c}77.5 \pm 56.0 \\
(26.7-258.0)\end{array}$ & $\begin{array}{c}39.3 \pm 30.3 \\
(20.0-151.0)\end{array}$ \\
\hline Irori & $\begin{array}{c}25.0 \pm 1.5 \\
(21.7-27.5)\end{array}$ & $\begin{array}{c}4.9 \pm 4.4 \\
(1.0-15.2)\end{array}$ & $\begin{array}{c}6.9 \pm 0.9 \\
(5.8-8.6)\end{array}$ & $\begin{array}{c}75.9 \pm 18.0 \\
(41.4-120.0)\end{array}$ & $\begin{array}{c}41.7 \pm 10.8 \\
(23.3-67.5)\end{array}$ \\
\hline Idi & $\begin{array}{c}25.9 \pm 1.7 \\
(22.3-29.0)\end{array}$ & $\begin{array}{c}7.9 \pm 4.8 \\
(3.0-17.1)\end{array}$ & $\begin{array}{c}6.9 \pm 0.8 \\
(5.3-8.5)\end{array}$ & $\begin{array}{l}46.7 \pm 16.6 \\
(22.8-70.7)\end{array}$ & $\begin{array}{c}24.7 \pm 11.2 \\
(10.0-49.8)\end{array}$ \\
\hline Isopa & $\begin{array}{c}26.3 \pm 1.5 \\
(23.7-28.5)\end{array}$ & $\begin{array}{c}8.1 \pm 4.9 \\
(1.5-17.2)\end{array}$ & $\begin{array}{c}6.9 \pm 0.8 \\
(6.0-8.5)\end{array}$ & $\begin{array}{c}47.9 \pm 19.8 \\
(23.3-106.9)\end{array}$ & $\begin{array}{c}24.7 \pm 12.2 \\
(10.0-63.9)\end{array}$ \\
\hline
\end{tabular}

Electrical conductivity varied widely in the different water bodies. The overall mean conductivity value of the rivers was $63.0 \pm 34.5 \mu \mathrm{S} / \mathrm{cm}$. Bareke River had the highest mean conductivity value $(77.5 \pm 56.0 \mu \mathrm{S} / \mathrm{cm})$ while Idi River had the least value $(46.7 \pm 16.6 \mu \mathrm{S} / \mathrm{cm})$ (Table 3$)$. The minimum value $(22.8 \mu \mathrm{S} / \mathrm{cm})$ was recorded in Idi River in January, 2012 while the maximum value $(258.0 \mu \mathrm{S} / \mathrm{cm})$ was recorded in Bareke River in October, 2011. Conductivity varied significantly with river bodies $(\mathrm{P}<0.05)$ but variation was not significant with seasons. Conductivity showed negative correlations with most of the snail species. More importantly was the significant negative correlation between conductivity and abundance of L. lybicus $(\mathrm{r}=-0.262 ; \mathrm{P}<0.05)$. A significant positive relationship was however observed between conductivity and abundance of B. senegalensis $(\mathrm{r}=0.269 ; \mathrm{P}<0.05)$.

The overall mean value for total dissolved solids in all the water bodies was $32.5 \pm 19.4 \mathrm{mg} / \mathrm{L}$. Irori River had the highest mean total dissolved solids value $(41.7 \pm 10.8 \mathrm{mg} / \mathrm{L})$ while Idi and Isopa Rivers had the least mean value (each $24.7 \mathrm{mg} / \mathrm{L}$ ). The total dissolved solids like conductivity varied significantly with river bodies $(\mathrm{P}<0.05)$ but was not significant with seasons.

\section{Relationships between snails}

Melanoides tuberculata correlated negatively with G. costulatus, L. lybicus, P. moerchi and S. augustus. However, $M$. tuberculata showed a significant positive correlation with the abundance of Ferrissia sp. $(\mathrm{r}=0.462$; $\mathrm{P}<0.05)$ and L. natalensis $(\mathrm{r}=0.308 ; \mathrm{P}<0.05)$. L. lybicus showed negative relationships with $B$. senegalensis $(\mathrm{r}=-0.240 ; \mathrm{P}<0.05)$, $S$. augustus, B. camerunensis, Ferrissia sp and L. natalensis. However, L. lybicus correlated positively with $B$. globosus. Other important relationships include the significant positive relationship between $B$. senegalensis and $S$. augustus $(\mathrm{r}=0.657 ; \mathrm{P}<0.01)$, B. globosus and $B$. jousseaumei $(\mathrm{r}=0.30 ; \mathrm{P}<0.05), B$. camerunensis and B. senegalensis $(\mathrm{r}=0.841 ; \mathrm{P}<0.01)($ Table 4$)$.

\section{Discussion}

Although shell characteristics suggest an identification of Bulinus camerunensis, a first report of such in Nigeria freshwater habitats, this needs to be confirmed by mo-

Table 4. Relationships between physico-chemical parameters and snail density

\begin{tabular}{|c|c|c|c|c|c|c|c|c|c|c|c|c|c|c|c|c|}
\hline & Temp & $\mathrm{pH}$ & $\mathrm{DO}$ & TDS & Cond & Mel & Gyr & Lan & B.g & B.s & Pot & Seg & B.c & Fer & L.n & B.j \\
\hline Temp & 1 & .07 & -.16 & -.13 & -.14 & -.17 & $.34^{*}$ & -.14 & $.27^{*}$ & -.03 & .10 & -.11 & -.03 & -.06 & -.03 & .09 \\
\hline $\mathrm{pH}$ & & 1 & .03 & .16 & -.08 & .00 & $.29^{*}$ & -.21 & .15 & .10 & -.03 & .07 & -.00 & .04 & -.04 & .04 \\
\hline $\mathrm{DO}$ & & & 1 & $-.25^{*}$ & $-.26^{*}$ & .17 & .11 & $.39^{*}$ & .18 & -.07 & .15 & -.08 & -.06 & $.36^{*}$ & $.32^{*}$ & $.31^{*}$ \\
\hline TDS & & & & 1 & $.97^{*}$ & -.02 & -.17 & $-.27^{*}$ & -.22 & $.29^{*}$ & -.14 & .10 & $.24^{*}$ & -.16 & -.09 & -.14 \\
\hline Cond & & & & & 1 & -.04 & -.22 & $-.26^{*}$ & -.22 & $.27^{*}$ & -.13 & .11 & .22 & -.17 & -.10 & -.14 \\
\hline Mel & & & & & & 1 & -.02 & -.05 & .00 & .13 & -.06 & -.03 & .06 & $.46^{*}$ & $.31^{*}$ & -.05 \\
\hline Gyr & & & & & & & 1 & .03 & $.23^{*}$ & .02 & .18 & .00 & -.08 & -.04 & -.06 & -.06 \\
\hline Lan & & & & & & & & 1 & .12 & $-.24^{*}$ & .01 & -.17 & -.17 & -.06 & -.02 & .02 \\
\hline B.g & & & & & & & & & 1 & .03 & .08 & .09 & -.07 & .06 & .08 & $.30^{*}$ \\
\hline B.s & & & & & & & & & & 1 & -.00 & $.66^{*}$ & .84 & .08 & .03 & -.04 \\
\hline Pot & & & & & & & & & & & 1 & -.02 & -.02 & .13 & -.05 & -.03 \\
\hline Seg & & & & & & & & & & & & 1 & $.61^{*}$ & .01 & -.05 & -.03 \\
\hline Hom & & & & & & & & & & & & & .00 & -.08 & -.07 & -.04 \\
\hline B.c & & & & & & & & & & & & & 1 & .01 & -.02 & -.03 \\
\hline Fer & & & & & & & & & & & & & & 1 & .09 & -.04 \\
\hline L.n & & & & & & & & & & & & & & & 1 & -.02 \\
\hline & & & & & & & & & & & & & & & & \\
\hline
\end{tabular}

Temp - Temperature, DO - Dissolved Oxygen, TDS - Total Dissolved Solids, Cond - Conductivity, Mel - M. tuberculata, Gyr - G. costulatus, Lan - L. lybicus, B.g - B. globosus, B.j-B. jousseaumei, B.s - B. senegalensis, Pot - P. moerchi, Seg - S. augustus, B.c-B. camerunensis, 
lecular analysis of the samples. An earlier report on the snail intermediate hosts of Schistosoma has revealed the occurrence of B. jousseaumei in Isopa River (Salawu \& Odaibo, 2012). The ecology of the snail as influenced by the physicochemical parameters of the river and its role in Schistosoma transmission has also been reported (Salawu \& Odaibo, 2012). Bulinus camerunensis has only been reported in Cameroon and its characteristic shell and exceedingly small radula teeth separate it from all other Bulinus (Mandahl-Barth, 1965). Although it is a known intermediate host of Schistosoma haematobium in Cameroon (Brown, 1994), its status as intermediate host of Schistosoma in Nigeria is not known as no infected individuals were discovered in the present study.

The probable influence of water flowing from bordering countries in the introduction of alien snail species into these river bodies has been reported earlier (Salawu \& Odaibo, 2012). Certain long distance migratory birds employed by aquatic snails for their dispersion have also been incriminated (Wesselingh et al., 1999).

Of the thirteen species of snail encountered, B. pfeifferi and B. globosus are established intermediate hosts of schistosomiasis in Nigeria (Olofintoye \& Odaibo, 1999; Oladejo $\&$ Ofoezie, 2006). However, the lack of infected $B$. pfeifferi and B. globosus is surprising in such highly endemic community with over 50 and $20 \%$ prevalence of urogenital schistosomiasis in school children and pregnant women respectively (Salawu \& Odaibo, 2013, 2014). Although, our earlier study (Salawu \& Odaibo, 2013) reported the occurrence of infected B. jousseaumei using the classical method of cercariae shedding (Salawu \& Odaibo, 2012), their absence in other potential intermediate hosts cannot be proven, hence a more reliable method of infection detection in snails is advocated.

The higher density of snails recorded in the dry season could have been due to the indirect impacts of flourishing microflora (food supply) and aquatic macrophytes during the season. The macrophytes supply the water with dissolved oxygen and also provide suitable surface on which the snails can crawl and deposit their egg masses. The low water current in the dry season could also offer a stable environment for snails to lodge onto surfaces and not being washed away (WHO, 1965). During the wet season, rainfall affects water movement and temperature, thereby, affecting the distribution and density of the aquatic snails (Appleton, 1978; Sturrock, 1993). Snail intermediate hosts of Schistosoma are intolerant of strong currents, and breeding colonies are not found in swift flowing streams or water bodies; they are usually found in areas where the velocity off low is below $40 \mathrm{~cm} / \mathrm{s}$ (Jones, 1993). This probably accounts for most of the snails in our study being recovered along the littoral zone; where the water current velocity is very low.

Temperature has been recognized as an important factor on any biotope especially freshwater (Hira, 1970). Several studies have reported the influence of temperature on certain stages of aquatic snails. The optimum temperatures for hatching $B$. globosus eggs is $25-28^{\circ} \mathrm{C}$ while at higher temperatures, hatching rate and survival decreases (Madsen, 1985). Egg production in Biomphalaria spp. has been shown to reduce at temperatures above $30^{\circ} \mathrm{C}$ due to pathological changes in the reproductive system of the snails (Madsen, 1985).High temperature causes thermal stress in snail vectors and shows an inverse relationship with dissolved oxygen (Hofkins et al., 1991).The temperature range of $21.7-29^{\circ} \mathrm{C}$ recorded in all river bodies during the study appears therefore to be favourable to the aquatic snails, as there were no significant changes in temperature throughout the sampling seasons.

The mean $\mathrm{pH}$ value in all the water bodies in the present study was within favourable limits for aquatic snail development (Boelee \& Laamrani, 2004). The higher mean pH value recorded during the dry season could be due to higher transparency of the water bodies resulting in active removal of carbon (iv) oxide and consequently production of oxygen through photosynthesis. The concentration of hydrogen ions is rarely a factor conditioning the presence and distribution of the snails (Madsen, 1985). This probably explains the insignificant relationships between abundance of snails and $\mathrm{pH}$ values in our study.

The mean dissolved oxygen $(6.1 \pm 4.6 \mathrm{mg} / \mathrm{L})$ recorded in this study falls within the desired range $(0.4$ and $16.0 \mathrm{mg} / \mathrm{L}$ ) for snail intermediate hosts (Harman \& Berg, 1971). The high dissolved oxygen content is a result of fast flowing river types washing away most of the polluting materials (Salawu \& Odaibo, 2012) and greater mixing due to the current. During one of the sampling months in Bareke River, a low dissolved oxygen $(1.02 \mathrm{mg} / \mathrm{L})$ recorded in June, 2010 could have resulted to the limited number of snails (only 2) sampled during this period. In addition, Bareke River with the least overall mean dissolved oxygen content recorded lower number of snails compared to Isopa River with higher dissolved oxygen content. A low concentration of oxygen, even if not immediately fatal to the snail, reduces its movements and thus impairs feeding and reproduction (Malek, 1958). An increase in snail abundance influenced by an increase in dissolved oxygen observed in this study has also been reported elsewhere (Boelee \& Laamrani, 2004).

The higher conductivity values reported in the wet season is unusual as other reports have indicated higher levels in the dry season (Tubonimi et al., 2010). The deposition of solute materials by run-off from surrounding environments followed by reduction in ion uptake due to instability of macrobenthos population in the microhabitat had been suggested to be the reasons for such variation (Salawu \& Odaibo, 2012). Seasonal variation in total dissolved solids and its relationship with snail abundance is similar to that of conductivity.

The relationships between aquatic snails differ from one species to the other. The negative correlations observed between $M$. tuberculata and some bulinids and planorbids are similar to other reports (Madsen, 1992; Giovanelli et al., 2005). The diet of $M$. tuberculata is similar to that of planorbids (Giovanelli et al., 2005), hence competition for food is possible. M. tuberculata has been reported to elimi- 
nate B. glabrata (Giovanelli et al., 2005). Part of this reduction could be attributed to the phenomenon of "one way competition" in which one species releases substances harmful to another into the water, as pointed out by Gomez et al.(1989) who reported that Thiara granifera probably produces one or more chemical factors that reduce the fecundity of B. glabrata. Another important factor is habitat type, which affects whether or not thiarids and planorbids are able to co-exist (Gumarães et al., 2001). The role of M. tuberculata as a biological control agent of molluscs has been questioned, concluding that it was able to co-exist with $B$. pfeifferi and other pulmonate snails in Kenya without displacing them completely (Mkoji et al., 1992). Similar mechanisms can be used to explain the interactions between L. lybicus and many of the planorbids especially $B$. senegalensis which showed a significant negative correlation with M. tuberculata. Since our result showed significant positive co-existence in the population of the planorbids (e.g. $B$. globosus and B. jousseaumei), it can be suggested that $L$. lybicus can serve as biocontrol for other planorbids other than B. senegalensis. Biological invasion of some caenogastropods especially $M$. tuberculata has also been reported to cause decline in the population of Biomphalaria glabrata in Martinique and Guadeloupe islands (Pointier et al., 2011). One potential limitation in this study was the identification of snails based on morphological characteristics alone. The use of more sensitive molecular tools for future studies to verify the identified species would be of importance especially in the separation of ambiguous Bulinus africanus groups. Also, the 20 minutes sampling duration may not have been sufficient owning to relatively small number of snails recovered.

\section{Conclusion}

Our findings showed that the survival of freshwater snails in the habitat is to a large extent dependent on the physicochemical properties of the water of which dissolved oxygen is the most important. Interactions between snails also gave some insights to the biocontrol potentials of Melanoides tuberculata and Lanistes lybicus against potential intermediate hosts of schistosomes. Therefore, for all encompassing Schistosoma control strategies in the study area, the use of competitor snails will play a major role in reducing transmission.

\section{Acknowledgements}

Authors acknowledge Dr T.K. Kristensen of MandahlBarth Research Centre, DBL-Section of Parasitology Health and Development, Institute of Veterinary Disease Biology, University of Copenhagen, Denmark for helping to authenticate the identified snail species. This study is partly funded by UI/MacArthur Multidisciplinary grant of University of Ibadan, Nigeria awarded to ABO and University of Ibadan Postgraduate School Scholarship awarded to OTS. Authors also acknowledge the two anonymous reviewers whose contributions further improved the output of this manuscript. The study forms part of OTS Doctoral Thesis.

\section{References}

AJAO, E. A. (1990): The influence of domestic and industrial effluents on populations of sessile and benthic organisms in Lagos Lagoon. Ph.D Thesis, University of Lagos, Nigeria $411 \mathrm{pp}$

Appleton, C. C. (1978): Review of literature on biotic factors that influence the distribution and life cycles of bilharziasis intermediate host snails. Malacol. Rev., 11: 1-25

BOELEE, E., LAAMRANI, H. (2004): Environmental control of schistosomiasis through community participation in a Moroccan oasis. Trop. Med. Int. Health, 9(9): 997 - 1004. DOI: 10.1111/j.1365-3156.2004.01301.x

BROWN, D. S. (1994): Freshwater snails of Africa and their medical importance. Taylor \& Francis, London.

Clennon, J. A., Mungai, P. L., Muchiri, E. M., King, C. H., Kitron, U. (2006): Spatial and temporal variations in local transmission of Schistosoma haematobium in Msambweni, Kenya. Am. J. Trop. Med. Hyg., 75: 1034 - 1041 EkPo, U. F., Mafiana, C. F., Adeofun, C. O., Solarin, A., IDOwU, A. B. (2008): Geographical information system and predictive risk maps of urogenital schistosomiasis in Ogun State, Nigeria. BMC Infect. Dis., 8: 74. DOI: 10.1186/1471-2334-8-74

Giovanelli, A., DA Silva, C. L., Leal, G. B. E. \& BAPTISTA, D. F. (2005): Habitat preference of freshwater snails in relation to environmental factors and the presence of the competitor snail Melanoides tuberculatus (Müller, 1774). Mem. Inst. Oswaldo Cruz, 100(2): 169 - 176

Gomez, J. D., VArgas, M., MALEK, E. A. (1989): Biological control of Biomphalaria glabrata by Thiara granifera under laboratory conditions. Trop. Med. Parasitol., 41(1): $43-45$

Guimarães, C. T., De Souza, C. P., Soares, D. M. (2001): Possible Competitive Displacement of Planorbids by Melanoides tuberculata in Minas Gerais, Brazil. Mem. Inst. Oswaldo Cruz, 96: 173-176

Hamburger, J., Hoffman, O., Kariuki, H. C., Muchiri, E. M., Ouma, J. H., Koech, D. K., Sturrock, R. F., KinG, C. H. (2004): Large-scale polymerase chain reaction-based surveillance of Schistosoma haematobium DNA in snails from transmission sites in coastal Kenya: a new tool for studying the dynamics of snail infection. Am. J. Trop. Med. Hyg., 71(6): $765-773$

HARMAN, W. N., BERG, C. O. (1971): The freshwater Gastropoda of central New York with illustrated keys to the genera and species. Search: Cornell Univ. Agric. Exp. Stat., 1: $1-68$

Hassan, A., Ntiaidem, U., Morenikeji, O., Nwuba, R., Anumudu, C., Adejuwon, S., Salawu, O., Jegede, A., ODAIBO, A. (2012): Urine turbidity and microhaematuria as rapid assessment indicators for Schistosoma haematobium infection among school children in endemic areas. Am. J. Infect. Dis., 8(1): 60 - 64. DOI: 10.3844/ajidsp.2012.60.64 HIRA, P. R. (1970): The temperature, $\mathrm{pH}$ and oxygen con- 
tent of water habouring the intermediate snail host of Schistosoma haematobium. Niger. J. Sci., 3: 131 - 138

Hofkins, B. V., MoKoJI, G. M., KeOchi, E. S. (1991): Controlling Schistosoma transmitting snails in Kenya by the North American Crayfish Procambus clarkii. Am. J. Trop. Med. Hyg., 45(3): 339 - 334

JONES, H. R. R. (1993): Water velocity as a control of aquatic snails in concrete canal systems for irrigation $(\mathrm{PhD}$ Dissertation) Loughborough University of Technology, United Kingdom.

Labbo, R., Ernould, J. C., DJibrilla, A., Garba, A., CHIPPAUX, J. P. (2008): Focusing of Schistosoma haematobium transmission in irrigated perimeters of the Niger valley (Niger): importance of malacological factors [Focalisation de la transmission de Schistosoma haematobium au sein des perimètres irrigués de la vallée di Niger (Niger): importance des facteurs malacologiques]. Rev. Epidemiol. Sante Publique, 56(1): 3 - 9. DOI: 10.1016/ j.respe.2007.10.011

MADSEN, H. (1985): Ecology and control of African fresh water Pulmonate snails. Notes of the Danish Bilharziasis Laboratory. Charlottenlund, Denmark

MADSEN, H. (1992): Food selection by freshwater snails in the Gezira irrigation canals, Sudan. Hydrobiologia, 228(3): 203 - 217. DOI: 10.1007/BF00006587

MafianA, C. F., EKPO, U. F., OJO, D. A. (2003): Urinary schistosomiasis in preschool children in settlements around Oyan Reservoir in Ogun State, Nigeria: implications for control. Trop. Med. Int. Health, 8(1): $78-82$. DOI: 10.1046/j.1365-3156.2003.00988.x

MALEK, E. A. (1958): Factors conditioning the Habitat of Bilharziasis Intermediate Hosts of the family Planorbidae. Bull. World Health Organ., 18(5 - 6): $785-818$

MANDAHL-BARTH, G. (1965): The species of the genus Bulinus, intermediate hosts of Schistosoma. Bull. World Health Organ., 33(1): 33 - 44

Margalef, R. (1951): Diversidad de especies en lascomunidales naturales. Publ. Inst. Biol. Apl., 9: 5 - 27

Mkoji, G. M., Mungai, B. N., Koech, D. K., Hofkin, B. V., LoKer, E. S., KiharA, J. H., Kageni, F. M. (1992): Does the snail Melanoides tuberculata have a role in biological control of Biomphalaria pfeifferi and other medically important African pulmonates? Ann. Trop. Med. Parasitol., 86(2): $201-204$

NDIFON, G. T., Ukoli, F. M. A. (1989): Ecology of freshwater snails in south-western Nigeria. I: Distribution and habitat preferences. Hydrobiologia, 171(3): 231 - 253. DOI: $10.1007 / \mathrm{BF} 00008146$

OladeJo, S. O., OfoEzIE, I. E. (2006): Unabated schistosomiasis transmission in Erinle River Dam, Osun State, Nigeria: evidence of neglect of environmental effects of developmental projects. Trop. Med. Int. Health, 11(6): 843 - 850. DOI: 10.1111/j.1365-3156.2006.01628.x

Olofintoye, L. K., OdAiBO, A. B. (1996): Influence of ecological factors in the population and infection dynamics of Bulinus globosus and Biomphalaria pfeifferi in the river Odo-Ona, Ibadan, Nigeria. Helminthologia, 33(2): 81 - 86. RECEIVED JULY 1, 2014
Onakomaya, S. O., Oyesiku, K., Jegede, F. J. (1992): Ogun State in Maps. 1st ed. Rex Charles Publication, Ibadan, Nigeria 172.

OpARA, K. N., UdOIDUNG, N. I., UKPONG, I. G. (2007): Genitourogenital schistosomiasis among preprimary schoolchildren in a rural community within the Cross River Basin, Nigeria. J. Helminthol., 81: 393 - 397

Owojori, O. J., Asaolu, S. O., Ofoezie, I. E. (2006): Ecology of freshwater snails in Opa Reservoir and Research Farm Ponds at Obafemi Awolowo University IleIfe, Nigeria. J. Appl. Sci., 6(15): 3004 - 3015. DOI: 10.3923/jas.2006.3004.3015

PoINTIER, J-P., DAVID, P., JARNE, P. (2011): Biomphalaria snails and larval trematodes; The biological control of the snail hosts of schistosomes: The role of competitor snails and biological invasions. In: TOLEDO, R., FRIED, B. (Eds) Biomphalaria snails and larval trematodes. Springer-Verlag, pp. $215-238$

Rollinson, D., Stothard, J. R., Southgate, V. R. (2001): Interactions between intermediate snail hosts of the genus Bulinus and schistosomes of the Schistosoma haematobium group. Parasitology, 123: 245 - 260. DOI: 10.1017/S0031182001008046

Rudge, J. W., Stothard, J. R., Basáñez, M-G., Mgeni, A. F., Khamis, I. S., KHAMIS, A. N.,Rollinson, D. (2008): Micro-epidemiology of urogenital schistosomiasis in Zanzibar: Local risk factors associated with distribution of infections among schoolchildren and relevance for control. Acta Trop., 105(1): 45 - 54. DOI: 10.1016/j.actatropica.20 07.09.006

SAlawU, O. T., OdAiBO, A. B. (2012): Preliminary study on ecology of Bulinusjousseaumei in Schistosoma haematobium endemic rural community of Nigeria. Afr. J. Ecol., 51(3): 441 - 446. DOI: 10.1111/aje.12054

SAlawU, O. T., OdAIBO, A. B. (2013): Schistosomiasis among pregnant women in rural communities in Nigeria. Int. J. Gynaecol. Obstet., 122(1): 1 - 4. DOI: 10.1016/ j.ijgo.2013.01.024

SAlAWU, O. T., ODAIBO, A. B. (2014): Urogenital schistosomiasis and urological assessment of hematuria in preschool-aged children in rural communities of Nigeria. $J$. Pediatr. Urol., 10(1): 88 - 93. DOI: 10.1016/j.jpurol.20 13.06.010

StURROCK, R. (1993): The parasites and their life cycle. In: Jordan, P., WebBe, G., Sturrock, R. F. (Eds), Human Schistosomiasis. CAB International, Wallingford $1-32$.

Tubonimi, J. K. I., Omubo, A., Herbert, O. S. (2010): Assessment of water quality along Amadi Creek in Portharcourt, Nigeria. Sci. Afr., 9(1):150 - 162

Wesselingh, F. P., CAdÉE, G. C., Renema, W. (1999): Flying high: on the air-borne dispersal of aquatic organisms as illustrated by the distribution histories of the gastropod genera Tryonia and Planorbarius. Geol. Mijnbouw, 78: $165-174$

WORLD HEALTH ORGANISATION (1965): Snail control in the prevention of Bilharziasis. Report of WHO Expert Committee, Geneva 11 - 12, 63 - 85,123 - 128, 214

ACCEPTED JULY 23, 2014 